\title{
TEACHERS' ATTITUDES AND TECHNIQUES TOWARDS EFL WRITING IN EGYPTIAN SECONDARY SCHOOLS
}

\author{
HOSAM DARWISH ${ }^{1}$ \\ Independent Researcher
}

\begin{abstract}
In 2008, the Egyptian Ministry of Education introduced a new national textbook, Hello for Secondary Schools, which recommends a shift in EFL teachers' instructional practices. Since then, very little attention has been paid to teachers' techniques in EFL writing classes. Hence, this paper aims at investigating teaching writing practices in secondary schools and exploring the teachers' attitudes towards EFL writing skills in addition to exploring the difficulties that teachers encountered in EFL writing lessons.
\end{abstract}

The paper depends on data triangulation through administering two questionnaires: one to 44 teachers and the other to 24 students, and conducting semi-structured interviews with 11 teachers. Both teachers and students are asked to describe teaching practices in EFL writing classes while the open-ended questions and interviews collected data about the teachers' difficulties in writing lessons.

The questionnaires indicate that teachers have negative attitudes towards teaching writing, and most of their practices are still traditional. Five factors have influenced teachers' practices: backwash of the test, teachers' professional development, students' culture of reading and large classes. The paper recommends there has to be a necessary change in the students' examination system, and ongoing teachers' professional development should be considered. Finally, a teaching model and implications are suggested.

Key words: Teacher's techniques, attitudes, EFL writing, Egyptian secondary schools

\section{Introduction}

In recent years, Egyptian researchers have become increasingly interested in EFL writing. Attempts are often made to change teaching and learning of languages in the Egyptian context, but these are not always monitored, especially at classroom level. There are important reasons for undertaking this paper. First, there have been few attempts to investigate teachers' practices and attitudes in EFL writing classes after adopting 'Hello Textbook' at secondary schools in Egypt in the academic year 2008/2009. Second, little research can be found that directly addresses the public secondary schools context; most of the literature has been in the tertiary level.

\section{Context and background of the paper}

Acquiring English is a difficult issue among EFL learners, especially Arab learners (Abbad, 1988; Rabab'ah, 2005). It has been found that most language learners at all levels believe that writing is one of the most difficult language skills to master (Maclntyre \& Gardner, 1989; Abdel-Latif, 2007) or a sophisticated skill compared with other skills (Abu Shawish \& Atea, 2010).

English is the first and most commonly used foreign language in Egypt. It is a highly valued language in both public and private Egyptian schools to the extent that it was introduced as a mandatory subject to first year primary in 2003/2004. EFL writing is very important for secondary school students as it prepares them for academic writing which is the medium of written communication in most universities in Egypt. Basically, there is one unified English language textbook for all students in each grade in the Egyptian

\footnotetext{
1 Contact email: hos_dar@yahoo.com
} 
schools. This national textbook is compulsory for all students in the public and the private sectors, and the final exam is based on it.

In recent years, the Egyptian government has accorded greater priority to improving the education system. Accordingly, a new textbook series Hello! English for Secondary Schools: Year One, Year Two, and Year Three' has been introduced to the general secondary stage since the academic year 2008-2009. The main aim of this series is to further equip students with the necessary language, thinking and study skills to communicate effectively and understand competently spoken and written English. Additionally, the aim of the EFL writing tasks is to help students write different types of texts, varied in length, on familiar themes and topics, take notes through speech or from a text, and to translate from Arabic to English and vice-versa (Ministry of Education (MOE), 2014). Moreover, the new textbook requires an instructional shift from the traditional product-oriented writing into writing as a process.

\section{Research questions}

Taking the paper aims into account, the research questions of this paper are as follow:

1. What are the teachers' attitudes towards EFL writing?

2. What are the teachers' practices in EFL writing classes?

3. What are the students' perceptions towards their teachers' EFL writing practices?

4. How do teachers perceive their teaching EFL writing difficulties and problems?

\section{Literature Review}

\subsection{EFL writing from product to process}

The Product Approach has been known as a traditional approach for teaching writing (Murray, 1980). This approach has been practiced widely since the 1950s well into 1970s. The emphasis on written product is clear in the fact that the teacher only responds to the composition once it is finished, and not before or while it is in progress (Jordan, 1997). Within this approach, teaching writing is regarded mainly as teaching mechanics: punctuation, spelling, and correct usage. In this perspective the teacher plays a primary role as an examiner (Zamel, 1987). Classroom time chosen for writing is normally allotted to drills and exercises on mechanics or grammar. It focuses on the final product, the coherent and the error-free text (Nunan, 1999). The product approach involves building up a list of skills that are needed to acquire before producing texts.

This approach was adopted in Egypt for many years. Most Egyptian researchers believed that the product approach resulted in a remarkable weakness in Egyptian students EFL writing (Salem, 2007). In addition that Egyptian students lost creativity; they became dependent on their teachers and passive listeners most of the lessons (Ahmad, 2010). On the other hand, the teaching method has been mostly teacher-centred and lecturing has been the most commonly method for teaching. This approach has developed students' tendency to memorise extracts from texts and recall them when they need. It is a big problem if they are asked to write about a topic without being given previous practice (Salem, 2007).

Therefore, there was a need for a new textbook with a new writing approach to encourage students to think, plan, search for ideas, develop, organise, review their writing and above all meet the requirements of examinations and academic life. There was a demand for an approach where the main concern of the teacher is to help learners develop their ideas, focus less on a perfect final draft product than the development of successive drafts of a text (Nunan, 1999), and writers are encouraged to get their ideas onto paper without worrying too much about formal correctness in the initial stages and learn the linguistic, cultural and rhetoric norms of the new language. Evidently, ' Hello for Secondary Schools Series' was introduced in 2008 as a component of the standards-based curricula reform.

The Process Approach emerged as a reaction to the Product Approach; it mainly focuses on the stages of writing such as planning, drafting, revisiting or redrafting and editing (Harmer, 2007). Therefore, 
the Process Approach tends to focus more on varied classroom activities involving multiple stages (Zeng, 2005).

The Process Writing Approach involves teaching pupils strategies to help them express themselves in writing through the act of writing. According to Mahon (1992), students experience five interrelated steps before the final products come out. These steps include pre-writing, drafting, revising and editing, and publishing.

Pre-writing and brainstorming: In this process, teachers elicit ideas from students. Then, they help students organise their ideas by using mind maps or visuals.

Drafting: On completion of mind mapping exercises, students write their first draft. Guidance and help are probably necessary in this stage and students are reassured that the first draft will not be perfect.

Revising and editing: Students are supported to reshape their writing, e.g. check their spelling, grammar, punctuation etc., or change ideas. This can be achieved through self-editing, peer editing and teacher editing, as well.

Publishing: At the end of the process, students produce the final draft. Opportunities are created for students to share their final products with their classmates or in front of the class.

Research on the Arab ESL/EFL teachers' practices in the writing process classroom is still in its infancy and there remains much to be explored about that process. Though most of the previous studies confirmed the feasibility and practicality of the process writing approach to developing the EFL writing skills of Arabic speaking students, a few studies have been conducted in experimental contexts, under controlled practices and variables using samples of students and teachers (Al-Hosani, 2008; Al-Ashri, 2013). Yet, few studies have paid attention to the actual teaching context considering the problems around it, e.g. lack of resources and large classes. That is why this paper is important as it might reflect factual teaching EFL writing context in the Egyptian classrooms.

Given the significance of the teacher's role, there is a need to know more about what teachers actually do in EFL writing lessons when charged with applying a new approach of teaching writing, on what basis they resist or accept the innovation, and the extent to which they see themselves as agents of change (Carless, 2011).

\subsection{Challenges affecting EFL writing teaching}

To provide a valid and reliable view about the practicality and feasibility of the process writing in the Egyptian classrooms, many difficulties and problems that might affect the teaching and learning process should be considered. However, these difficulties will be titled as 'challenges' to give a positive attitude for implementing the approach. Reviewing the literature, four main challenges affecting teaching EFL writing were identified.

\section{Teachers' attitudes $\quad$ 2. Teachers' professional development \\ 3. Backwash of the examination system 4. Teaching large classes}

\subsubsection{Teachers' attitudes}

Teachers' attitudes and expectations are important factors in L2 writing classrooms (Dornyei, 2003; Hyland \& Hyland, 2001; Williams, 2003). Williams (2003) indicates that sound teaching methods could fail to produce significant progress in performance if the teachers do not believe that they can make a difference in the classroom and/or view students as having little or no competence. As Proctor (1984) has argued, to be effective, teachers must feel good about teaching and about students and believe that they can influence student learning.

Thus, the relationship between attitude and performance has been viewed as mutual, with each factor affecting the development of the other. All in all, SLA literature supports a relationship between attitudes 
towards a language and language achievement (Masgoret \& Gardner, 2003). Many researchers think that attitudes include cognitive, affective and behavioural components (Wenden, 1991). The cognitive component involves beliefs or perceptions about the objects or situations related to the attitude. The affective component refers to the feelings and emotions that one has towards an object, 'likes' or 'dislikes', 'with' or 'against'. The behavioural component means that certain attitudes tend to prompt someone to adopt particular behaviours. It can be pointed out that all these types of attitudes are interactive in a nonlinear shape. The cognitive impacts the behavioural and they both influence the affective element, and they can swap their roles.

A little literature discussed the relationship between attitudes and writing achievement (Graham et al, 2007). They defined writing attitude as an affective disposition involving how the act of writing makes the author feel, ranging from happy to unhappy. Even so, Bartscher et al (2001) say that writing attitude is highly effective on improving or obstructing writing achievement. The proposed study is noteworthy because it investigates how teachers' attitudes may affect their strategies in EFL writing classes.

\subsubsection{Teachers' professional development}

Teachers' development means providing teachers with opportunities to acquire new knowledge and beliefs about content, pedagogy, and learners (Darling-Hammond \& McLaughlin, 1995). Also, professional development programmes could encourage teachers collegiality which is very significant for most teachers for two main reasons as Jarzabkowski (2002) confirms: First, it may enhance better working relationships that may yield quality teaching and learning. Second, it encourages through social interaction a better emotional health environment among staff, which decreases emotional strain and burnout. As a result it leads to better teaching attitudes towards EFL writing. Also, the research on professional development refers to the significance of the idea of collectivity, collaboration and community (Day \& Sachs, 2004).

Since teaching is a complex job, training will certainly assist teachers to do their job better. However, this training and updating to their knowledge should be on-going as changing methods of teaching takes much time. Hayes (1997) claims that the notion of change in the method of teaching should not be scrutinized narrowly, because change does not inevitably mean doing something completely in a different way. Rather, it refers to 'a change in awareness or of the current practice' (Hayes, 1997, p. 4). The 'awareness' of one's teaching practices equals what Alexander (2008) refers to as the constant improvement in standards of teaching.

Unfortunately, there is a number of barriers that may hinder teachers' professional development in Egypt; in his Investigation into Professional Practical Knowledge of EFL Experienced Teachers in Egypt, AbdelHafez, (2010) referred to a variety of intervening contextual challenges to deter the actualisation of teacher knowledge and professional development, such as the EFL exam policy, lack of time, support and resources, mismatch between teacher purposes and students' expectations and needs, and large class size.

\subsubsection{Backwash of the examination system}

Another important factor that might be hindering teaching writing as a process is the washback. Backwash or wasback refers to the influence of testing on teaching and learning (Abdel-Latif, 2012). Examinations in Egypt, whether regular monthly assessments, promotion tests or more formal examinations such as GCSE (General Certificate of Secondary Education), have traditionally emphasised memorisation of facts; this has influenced the methods of both teaching and learning. Therefore, most teaching could be more precisely described as lecturing (Sorour, 1991) and most learning as memorisation learning. The high stakes nature of much of the testing, particularly at preparatory and secondary schools, confirms that the curriculum conforms to the examination system which affected even the culture of teaching where this atmosphere of students fear from exams have also given teachers the opportunity to teach to the test (Herrera, 1992).

Exploring teacher instructional practices within EFL secondary school class-rooms in Syria, Rajab (2013) found out that most teachers, during the interviews emphasised the significance of exams not only to their personal agendas, but also to the students', parents' and the school administration's agendas. 
Broad expectations were held about students' great success in the final exam. Because of the exam, the teaching styles of the teachers were geared towards serving this end (Ibid).In the same seam, while investigating the essay writing difficulties of Egyptian student teachers of English, Ahmad (2010) asserts that both students and their teachers seem to consider that their target is not how to write, but how to get a high score irrespective of teaching and learning. Likewise, Abdel-Latif (2012) conducted a similar study to the current one, but it was more generic, i.e. all language skills, he examined how a standards-based communicative curricular reform in general secondary school English in Egypt has changed teachers' classroom practices; he suggested that for this standards-based communicative curricular reform to serve as a catalyst for changes in instruction, there has to be another parallel reform in the students' examination system.

Thus, confirming Abdel-Latif's suggestions, it would seem important for active and effective teaching and learning, that there would need to be formal links between the bodies responsible for curriculum development, examinations and teacher's training.

\subsubsection{Teaching large classes}

Indeed, teaching a large class is a great challenge for teachers due to many reasons: First, managing students is rather difficult in large classes (Blatchford et al., 2007). Second, teacher-student relationship is negatively affected. Third, teachers' use of time for marking, planning, and assessment is a problematic issue in these classes. Furthermore, teachers find it difficult to motivate and involve students' interests in large classes (Ballantyne et. al., 2000). It can be pointed out that large classes affect the interaction between teacher and students and could probably affect collaborative tasks inside the classroom. Most teachers contend that they do not have collaborative activities in their classrooms because of the big number of students, so they have to lecture most of the time.

In the present study, the challenge of large classes is one of the difficulties facing the Egyptian teachers while teaching process writing; due to the over-population problem in Egypt, classes at secondary schools in Cairo range from 40-69 in different areas. However, it is argued that large classes could be an advantage for process writing as students can share many different ideas and exciting life experiences; this stimulates the students and enlivens those parts of your lesson where students can discuss and learn from each other (Sarkisian, 2010).

\section{Methodology \& Participants}

To acquire comprehensive profiles of teachers' practices and beliefs, the current paper employed mixed methods which combined quantitative (questionnaires) and qualitative data (interviews).

The teachers' questionnaire was developed to collect data concerning attitudes and techniques of teachers while instructing EFL writing, and another questionnaire was also developed to investigate students' perceptions towards teaching EFL writing. Interviews were conducted with teachers to seek deep data about teachers' EFL writing practices and explore the difficulties they faced while teaching EFL writing.

A sample of secondary school female and male teachers of English in Egypt took part in the study. They were all working in secondary schools in Cairo. The rationale for choosing Cairo governorate is based on the accessibility of recruiting participants. All participants agreed to take part in the study on a voluntary basis. The 44 teachers ( 32 males and 12 females) were chosen randomly to fit the purpose of the study. Similarly, 11 teachers ( 9 males and 2 females) from the 44 participants were interviewed. All teachers were Egyptian native-Arabic speakers.

On the other hand, 24 students (14 females and 10 males) in 3rd secondary grade from four schools in Cairo Governorate filled out the students' questionnaire, and 10 of them sent 10 writing tasks of unit one in the workbook. They were deliberately selected to investigate the teachers' practices; those students have been studying EFL at the secondary stage for about three years. The rationale of choosing 3rd grade students was their probable ability to provide a comprehensive picture covering the EFL writing instructional practices better than their younger peers in 2nd and 1st grade. The students' ages ranged from 16 to 18 years old. They have been studying English for 12 years. 3rd secondary year is the most 
important year for most students in Egypt for it is the year that determines whether they would join tertiary education or not. Additionally, English is very important for those students as it is the language of most universities.

Table 2 shows each of the research questions vis-à-vis the research instruments and the number of the target group used to help answer each research question.

Table 1: Research questions, instruments and target group

\begin{tabular}{|c|c|c|}
\hline Research Question & Research Instruments & Target \& Total Numbers \\
\hline $\begin{array}{c}\text { What are the teachers' attitudes } \\
\text { towards EFL writing? }\end{array}$ & $\begin{array}{c}\text { Teachers' Questionnaire } \\
\text { (Question 2) }\end{array}$ & 44 teachers \\
\hline $\begin{array}{c}\text { What are the teachers' practices } \\
\text { in EFL writing classes? }\end{array}$ & $\begin{array}{c}\text {-Teachers' Questionnaire } \\
\text { (Question 3) }\end{array}$ & 24 teachers \\
\hline $\begin{array}{c}\text { What are the students' } \\
\text { perceptions towards their } \\
\text { teachers' writing practices? }\end{array}$ & $\begin{array}{c}\text { Students' Questionnaire } \\
\text { (Questions 1 and 2) }\end{array}$ & 44 teachers \\
\hline $\begin{array}{c}\text { How do EFL teachers perceive } \\
\text { their teaching EFL writing } \\
\text { difficulties and problems? }\end{array}$ & $\begin{array}{c}\text {-Teachers' Questionnaire (open } \\
\text { ended questions) } \\
\text { (Question 4) } \\
\text {-Teachers' interviews }\end{array}$ & 11 teachers \\
\hline
\end{tabular}

\section{Findings \& Discussion}

\begin{tabular}{|c|c|c|c|c|c|c|} 
5.1.Research question (1) & \multicolumn{2}{c}{ Teachers' attitudes towards } & EFL & writing \\
\hline No & Attitudes & $\begin{array}{c}\text { Strongly } \\
\text { disagree }\end{array}$ & disagree & uncertain & agree & $\begin{array}{c}\text { Strongly } \\
\text { agree }\end{array}$ \\
\hline 1 & $\begin{array}{c}\text { I prefer teaching writing to } \\
\text { other skills. }\end{array}$ & 2 & 22 & 7 & 12 & 1 \\
\hline 2 & $\begin{array}{c}\text { EFL writing is an important } \\
\text { skill for students. }\end{array}$ & 0 & 2 & 4 & 32 & 6 \\
\hline 3 & $\begin{array}{c}\text { Priority should be given to } \\
\text { teaching writing }\end{array}$ & 8 & 19 & 8 & 6 & 3 \\
\hline 4 & $\begin{array}{c}\text { EFL writing lessons in } \\
\text { "Hello for 3rd Secondary } \\
\text { Grade" are interesting for } \\
\text { me. }\end{array}$ & 3 & 5 & 21 & 9 & 6 \\
\hline 5 & $\begin{array}{c}\text { EFL writing lessons are } \\
\text { more difficult and tiring for } \\
\text { me than other lessons. }\end{array}$ & 3 & 5 & 7 & 19 & 10 \\
\hline 6 & $\begin{array}{c}\text { Giving feedback in EFL } \\
\text { writing lessons is more } \\
\text { difficult than other skills. }\end{array}$ & 1 & 3 & 4 & 22 & 14 \\
\hline
\end{tabular}




\begin{tabular}{|c|c|c|c|c|c|c|}
\hline 7 & $\begin{array}{c}\text { Lack of resources affects } \\
\text { negatively my EFL writing } \\
\text { lessons. }\end{array}$ & 0 & 14 & 5 & 18 & 7 \\
\hline 8 & $\begin{array}{c}\text { I know the process writing } \\
\text { approach. }\end{array}$ & 5 & 7 & 16 & 11 & 5 \\
\hline 9 & $\begin{array}{c}\text { I know product writing } \\
\text { approach. }\end{array}$ & 3 & 5 & 19 & 12 & 5 \\
\hline 10 & $\begin{array}{c}\text { I am updated to the most } \\
\text { recent approaches of } \\
\text { teaching English especially } \\
\text { writing. }\end{array}$ & 1 & 22 & 10 & 4 \\
\hline
\end{tabular}

As seen in the figures above, the teachers' attitudes towards EFL writing practices are mostly negative. The figures show that about $87 \%$ have positive attitudes towards the importance of EFL writing, but only $29 \%$ prefer teaching it. This is clear when the majority of them consider EFL writing practices and feedback to be exhausting which is also confirmed by most teachers in the world as claimed by Zheng (1999) who says that many teachers of English have noted, acquiring the writing skill seems to be more laborious and demanding than acquiring the other language skills. Similarly, Ahmad (2010, p. 239) indicates that Egyptian essay writing teachers' attitudes towards their work is mostly negative, with six participants of eight commenting on it as 'difficult', 'hard', and 'challenging'. These negative behavioural attitudes might be resulted from different reasons: first, most teachers have been teaching in large classes characterised by physical as well as intellectual distance between teachers and students. Next, many teachers still use traditional teaching techniques, such as lecturing as noticed in the teaching practices data analysis. Consequently, they feel tired quickly and the lack of communication between them and students leads to boredom and negative attitudes.

On the other hand, nearly half of teachers surprisingly are unsure if 'Hello Textbook' is interesting or not. It could be that case that they do not care about the book because they are not usually consulted about new curricula.

It should be pointed out that teachers' negative attitudes and the uncertainty of making decisions could be related to their poor cognitive perceptions of EFL writing; only eight out of forty four teachers state that they are updated to the new teaching approaches, but the majority of them are uncertain and outdated. A big number of teachers have unclear idea about the Product Approach or the Process Approach of teaching writing, and this is confirmed during the interviews, as well. This uncertainty of teaching methods might develop negative attitudes for both teachers and students towards EFL writing teaching. Moreover, the teachers' negative attitudes towards teaching writing lessons seem to affect their willingness to teach it. They may have different attitudes if these variables (cognition and action) change.

\subsection{Research question (2) Teachers' techniques}

The teachers' techniques were divided into two:

1. The traditional techniques (items 1-2)

2. The Teacher's Guide techniques which include:
a) Pre-writing practices (items 3-4- 5)
b) Drafting practices (6-7-8)
c) Editing and revising practices (9-10-11-12)
d) Publishing practices (13-1
The traditional practices 
Beginning with the the traditional practices, most of the teachers $(84 \%)$ claimed that lecturing was less frequently used in their lessons. On the contrary, $58 \%$ of the students stated that lecturing was a common practice for their teachers; also worth noting is that roughly fifth of the students agreed with the teachers' views.

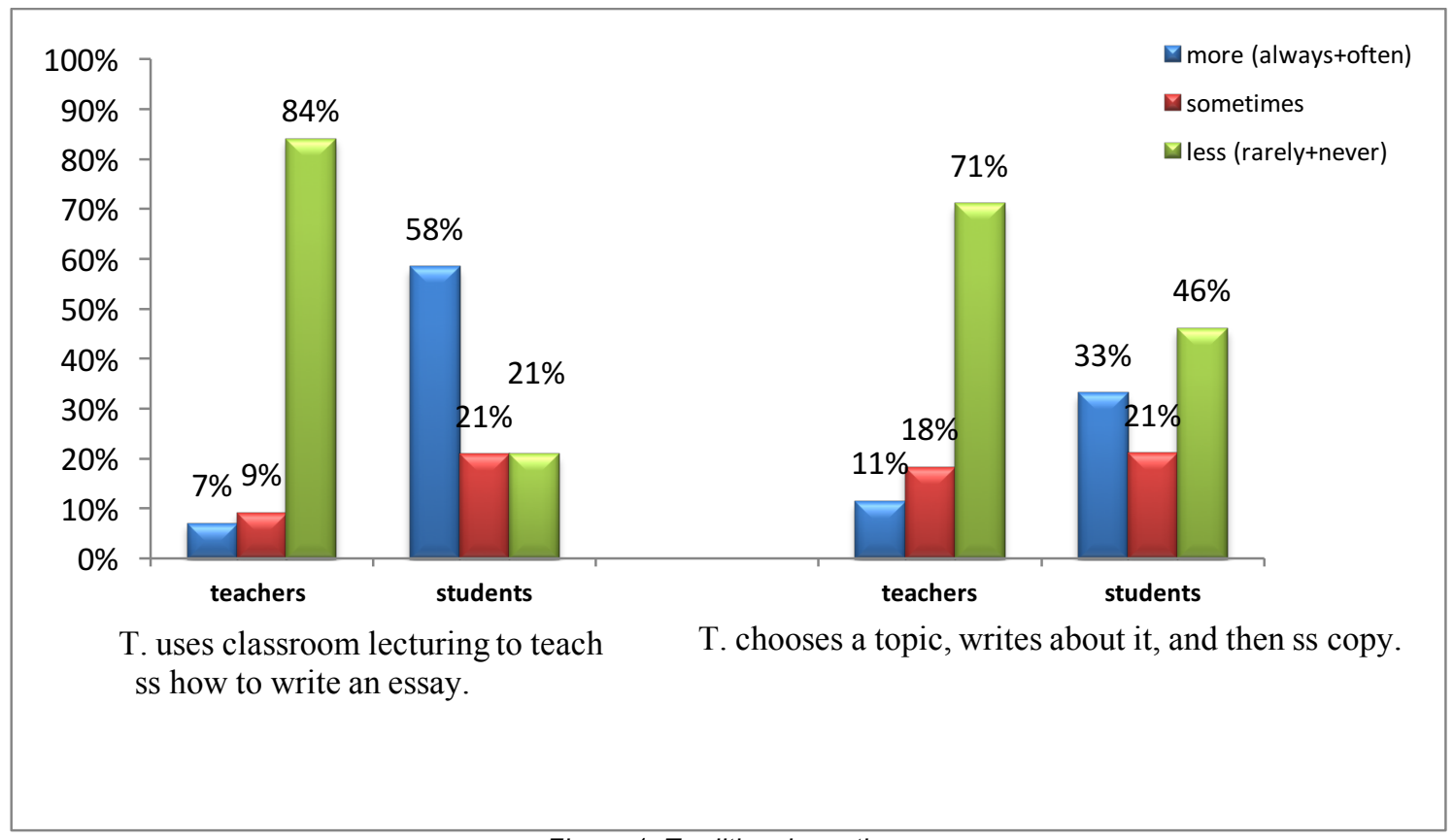

Figure 1: Traditional practices

Turning to choosing the topic of the essay, it can be seen that $71 \%$ of the teachers said that they rarely followed that traditional technique. Accordingly, a little less than half of the students supported the teachers' opinion; only about a third stated that their teachers used to do that traditional practice.

\section{Teacher's Guide techniques}

\section{Pre-writing practices}

As for the pre-writing practices, most of the teachers and the students agreed on the frequency of doing most of them in the classroom (see Figure 1). 


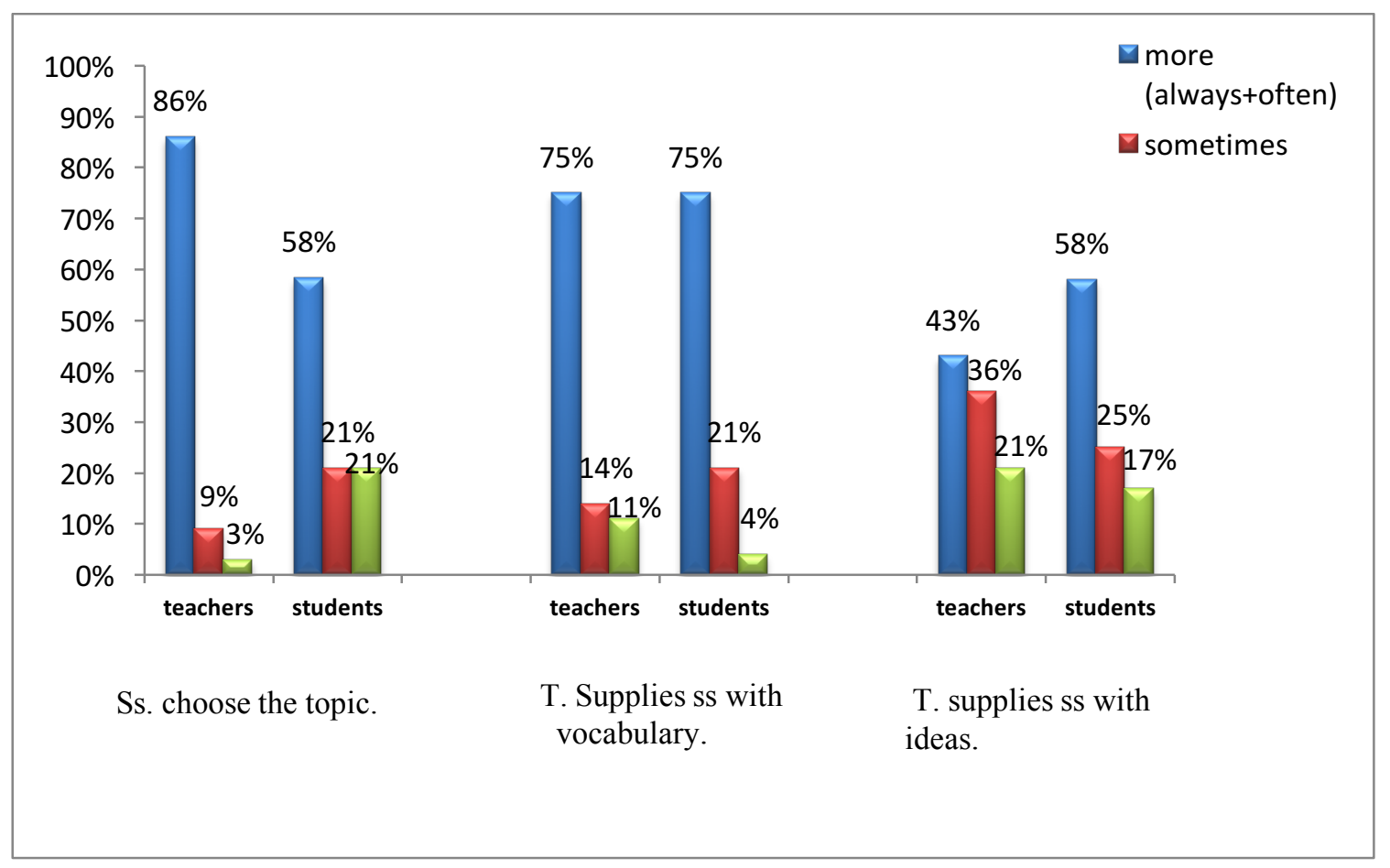

Figure 2: Pre-writing practices

To begin with the first item, a very high percentage of teachers (86\%) asserted that students used to choose the topics of their essays. On the contrary, almost one-third $(31 \%)$ of the students agreed with them while the highest percentage (more than half) confirmed that they did not choose the topics of their essays. On the other hand, it can be clearly seen that teachers and students showed an exact similar trend with the teachers' providing students with both vocabulary and notes; three quarters of both teachers and students gave positive responses concerning supplying vocabulary. Likewise, but with a lower percentage, both teachers and students confirmed that teachers used to provide their students with ideas for the writing ( $43 \%$ and $58 \%$ respectively) (see Figure 2 ).

\section{Drafting practices}

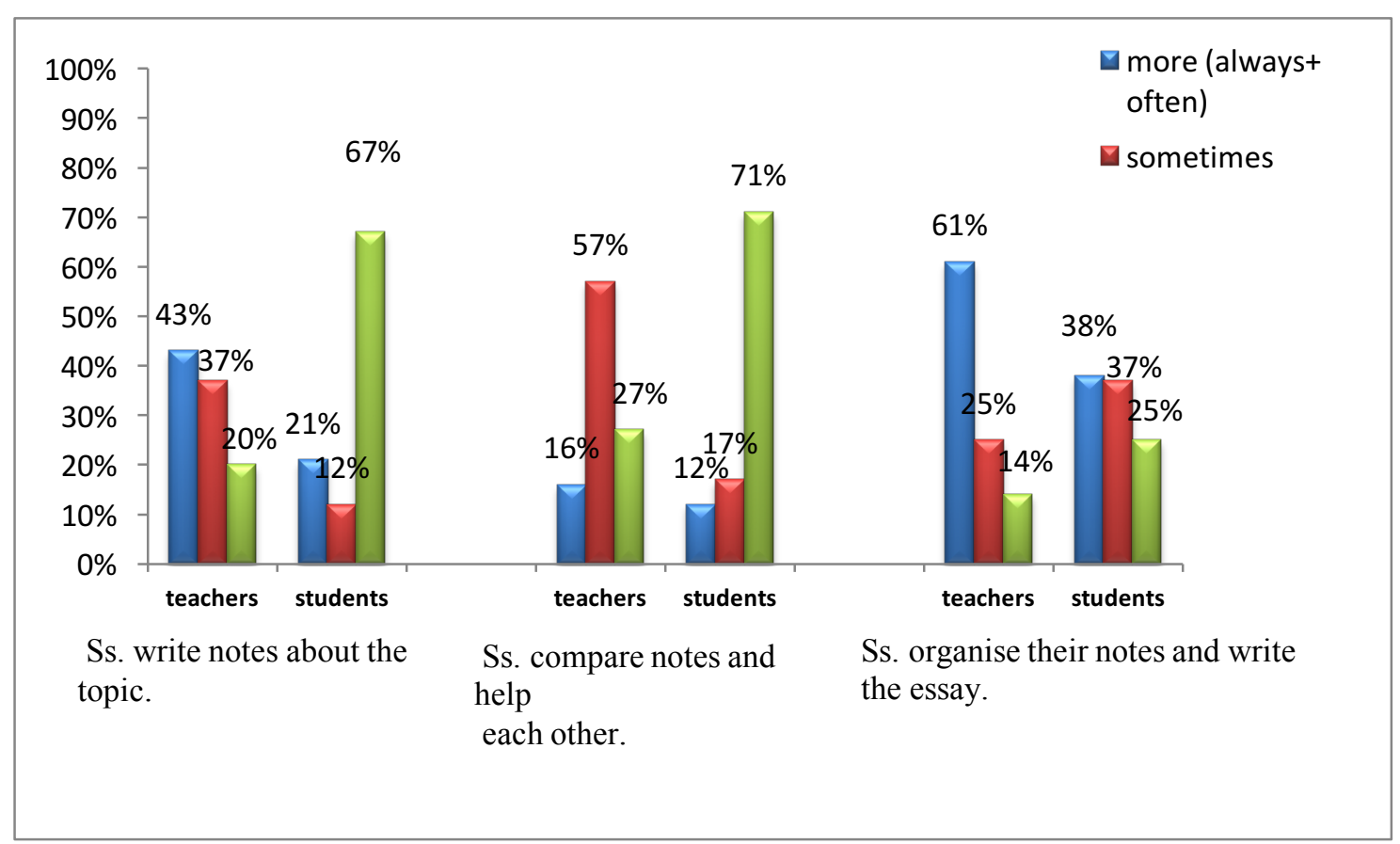

Figure 3: Drafting practices 
The drafting practices revealed a notable contrast between the teachers' and the students' views regarding to the first two practices. While about $43 \%$ of the teachers assured that their students used to write notes about the topic, a significant proportion of the students (67\%) opposed that opinion. It is clear that about $57 \%$ of the teachers had neutral opinions about students' comparing their notes with their peers, but a considerable number of the students $(71 \%)$ refuted this argument saying those practices rarely occurred. Nevertheless, the majority of both teachers and students agreed on the $3^{\text {rd }}$ item where 61 $\%$ of teachers and $38 \%$ of the students emphasised that students used to organise their notes and write the essay in writing lessons; it is also worth pointing out that about $37 \%$ of the students expressed neutral views (see Figure 3).

\section{Editing and revising practices}

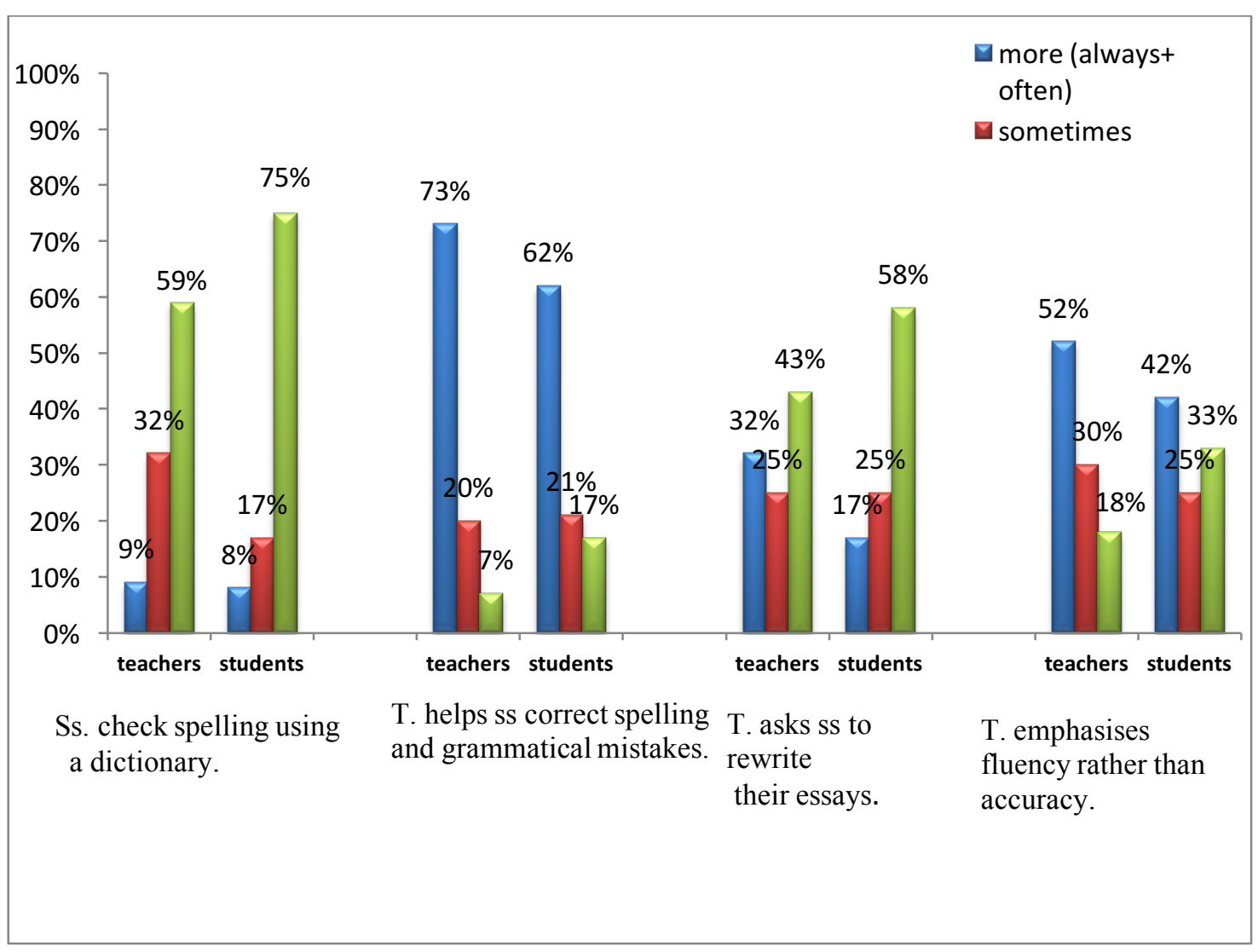

Figure 4: Editing and revising practices

Moving on to the editing and revising practices, both teachers and students showed almost similar trends. A significant percentage of teachers, as well as students (59 \% and $75 \%$ respectively) assured that students rarely used their dictionaries in writing lessons while the minority of both of them gave positive responses. Also, almost three quarters of the teachers and less than two thirds of students asserted that teachers used to help their students correct their spelling and grammatical mistakes. With the same accordance of opinion, $58 \%$ of the teachers and $43 \%$ of the students confirmed that the teachers did not use to ask students to rewrite their essays, but only about third of the teachers said that they did. With the same agreement, roughly half of the teachers gave a positive view on their emphasis on fluency rather than accuracy, whereas with $10 \%$ less than teachers, students had the same opinions; only $18 \%$ of the teachers and nearly third of the students said that teachers focused on accuracy more than fluency (see Figure 4). 


\section{Publishing practices}

Finally, the statistical results confirmed that teachers had difficulty in the publishing activities, the word 'sometimes' dominated most of the teacher's practices. More than half of the teachers showed neutral views concerning the first publishing practice. Similarly, about two thirds of the students argued that they did not use to be seated in groups and read each other's essay; however, to some extent, the students agreed with the teachers on the $2^{\text {nd }}$ item where $42 \%$ of students and $48 \%$ of teachers said that students sometimes read their essays aloud. The remarkable trend that can be observed in this item is that the responses (more, neutral and less) were to some extent proportioned (see Figure 5).

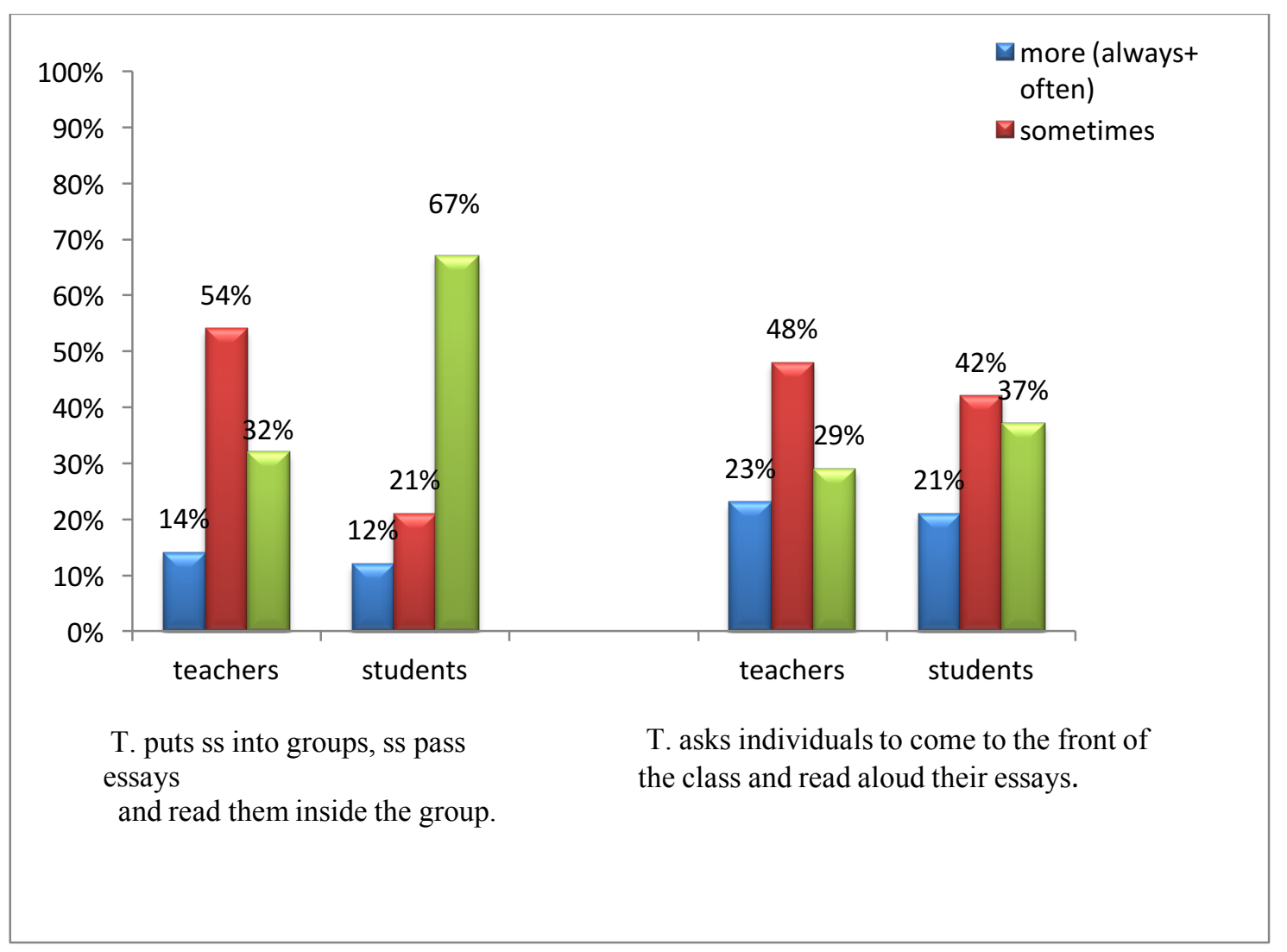

Figure 5: Publishing practices

It can be concluded that both teachers and students indicate that teachers do not adopt any clear approach while teaching EFL writing. Their practices do not correspond to the teacher's book guidelines. They are possibly affected by factors that may be internal or external. It can be clear that teachers and students have different views on most of these practices. About three quarters of teachers indicate that the traditional practices, such as lecturing or students' modelling an essay, are less frequently used in their writing lessons, but a big number of students disagree with them and refer that lecturing is most frequently used, and they sometimes copy their teachers' essays.

According to Hyland (2003), the teacher does not go beyond providing guidance and assistance to students. Teachers should be only facilitators (Hillocks, 1984). In their questionnaires, students consider writing supporting sentences to be the most difficult writing skill teacher find difficult to clarify for them. This probably gives implications that students struggle in writing supporting sentences. Accordingly, the prewriting data might give negative impression that the prewriting practices are more teacher-centred, and students do not get the chance to think by their own to generate ideas and look for the needed vocabulary.

Most of the data regarding to the drafting, the editing and revising and the publishing practices imply that they are used less frequent than the previous ones according to both teachers and students' views. The results indicate that the process writing practices that based on collaborative work and more studentcentred activities have not been successfully implemented. In contrast, the teacher-centred practices were 
more frequent, such as teachers' supplying vocabulary, notes or checking mistakes. The mismatch between teachers' responses and those of the students is just the priority of these activities; besides, the teachers' percentages are notably higher than students' which could imply that teachers want to draw a more communicative lesson view than students.

Therefore, these findings contradict the other findings in the literature that approved the process approach, such as (Mohamed, 1993; Al-Ashri, 2013) which were conducted under experimental controlled variables and context, i.e. small number of students, available resources and trained teachers. In the real classroom context, the teachers seem to fail to utilise the process writing techniques and are affected by the traditional strategies.

It can be argued that teachers are probably struggling to get rid of all the traditional practices. The findings show that teaching EFL writing in Egypt seems to be a combination of more traditional (teachercentred) and fewer process techniques (students-centred). Perhaps, the teachers' unsystematic and fuzzy practices resulted from their poor knowledge of the proper way of teaching writing. Teacher-centred classes can be physically and mentally exhausting for teachers. The internal and external factors that will be mentioned later might affect these practices. This confirms what Myles (2002) argues that EFL writing is a process which is affected by external factors, e.g. context, and/or internal factors, e.g. psychological and cognitive elements.

\subsection{Research question (3) Students perceptions towards teaching EFL writing}

Because the students of this study were not interviewed, it was significant to obtain their perceptions towards general issues in EFL writing lessons; the responses could emerge findings that might support the study. The following questions were included in first part of the questionnaire (items 4, 5, 6 and 7).

As shown in Figure 5, the students' responses were proportioned to most of the choices with small intervals among most of the percentages.

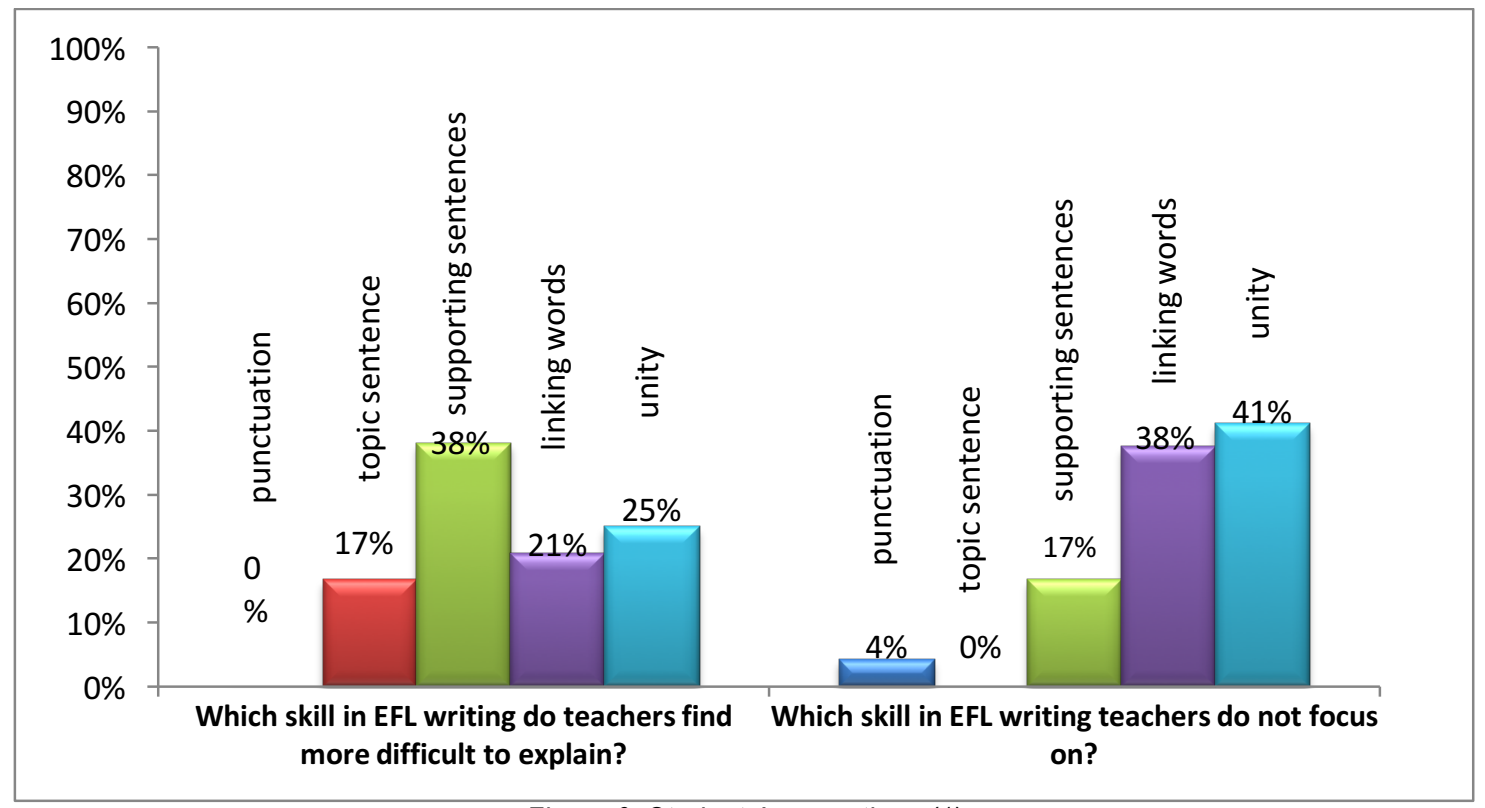

Figure 6: Students' perceptions (1)

To begin with the first question, $38 \%$ of the students believed that teaching how to generate supporting sentences was very hard for teachers while a quarter said 'unity' followed by 'linking words' $(21 \%)$. With regard to the skill which teachers did not focus on, about $41 \%$ mentioned 'unity, and then came linking words and supporting sentences with (38\% and $17 \%$ respectively.

Moving on to different questions, more than half of the students thought that the teachers took on the responsibility for facilitating writing skills and making writing lessons enjoyable according to the students' responses, as shown in the figure below. 


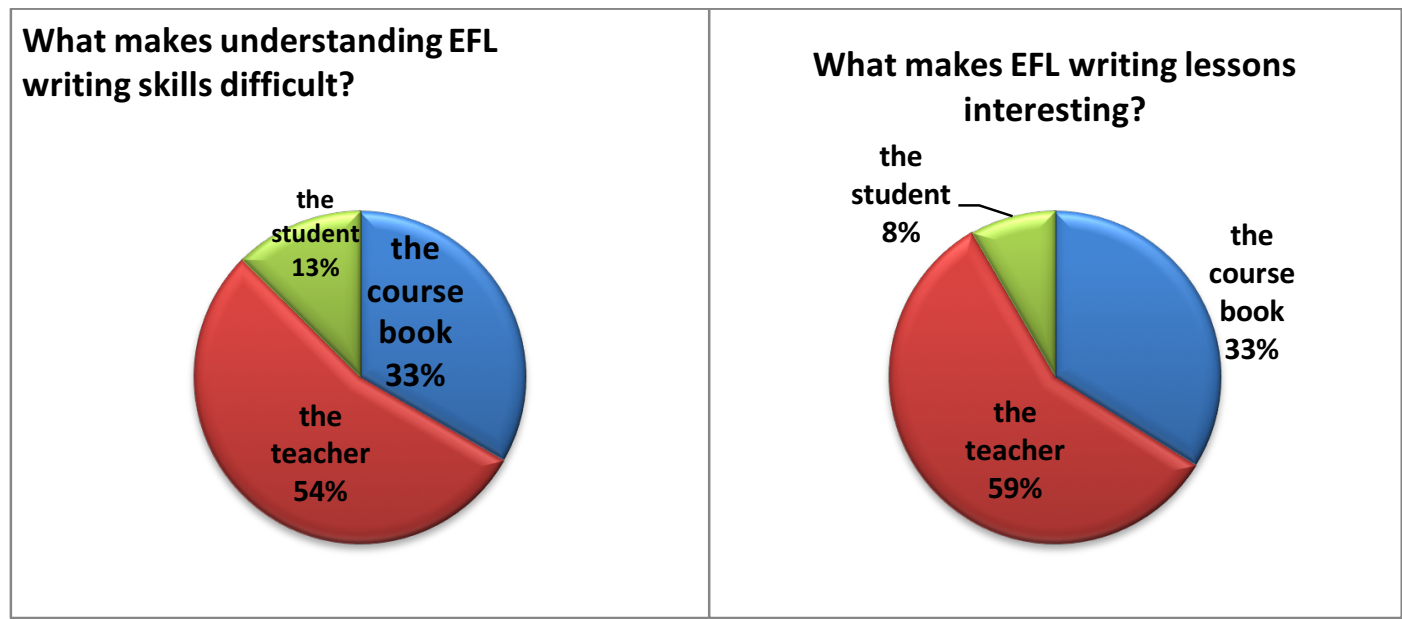

Figure 7: Students perceptions (2)

Though the data from the students' questionnaire draw a gloomy picture of the teachers' practices regarding to interactive and process writing teaching, more than half of the students believe that teachers are the main player of the learning process as they are able to make the lessons more interesting and facilitate the learning process emphasising what is said by Kavcar (2005) that the teacher is the most important element of an education system. This may indicate that the reform is supposed to begin from the teacher; the Egyptian Ministry of Education reform may achieve nothing if it does not include teachers' professional development in its future plans to improve education.

\subsection{Research question (4): Teachers' difficulties}

The interviews and the open-ended questions data indicate that the previously mentioned instructional practices are influenced by three main factors:

a) Instructional factors that include the teaching workload and the teacher's training and culture.

b) Learning factors that include learning to the test, students' low proficiency and students' culture of reading.

c) Contextual factors that include lack of time, lack of resources and large classes. Accordingly, the qualitative and quantitative results will be classified under four main themes, three of them were discussed in the literature review, namely washback, 'teachers' cultural and professional development' and teaching large classes while students' reading culture emerged as a new theme.

\section{- Washback}

The term washback was not mentioned in the questionnaire or the interviews, but it was identified from them. The washback of the exams is highly ranked by interviewed teachers to be the first obstacle that they encounter when teaching EFL writing. Students' needs are prioritised by teachers' techniques targeting the exam. Teachers neglect pair work, group work, students' interaction and thinking to generate ideas, and the publishing activities.

Interviewee 8: I have to concentrate on the parts in which students are tested. Otherwise, I will be classified as a bad teacher by students. I have to skip some writing activities or practices so as not to waste my students' time.

They focus only on checking spelling and grammar, providing ideas and vocabulary to reach to the final enhanced essay in a short time satisfying students' needs, but ignoring their role in the writing process. The students' role comes later when they memorise the main parts of this essay. This confirms 
what the literature says about the Egyptian context that most teaching could be more precisely described as lecturing and most learning as memorisation learning (Sorour, 1991).

Above all, because of the test, teachers and students seem to focus on the mechanics of the language rather than its rhetoric and cultural norms. The assessment criteria of the exams are based on grammatical, spelling and punctuation accuracy; these practices are product oriented and the process writing aim is to develop the thinking, creativity of learners and to make them well-acquainted with the cultural, rhetoric and linguistic norms of the target language.

It can be pointed out from the interviews and the practices that teachers' anxiety with student final examinations directly impact the way they prepare and deliver the writing lessons. These results are similar to what Rajab (2013) found out during his study at secondary schools in Syria and Ahmad's (2010) study with university teachers in Egypt as mentioned earlier in the literature review. The exam results for students, parents, principals and teachers are more important than acquiring the language, i.e. practising it properly. This resulted in an emphasis on teaching content rather than skills and fostered teaching about the language rather than teaching 'the use of the language for communication' (Ellis, 2005, p. 43). This naturally led to more teacher-centred practices, whereas the new textbook suggests that teachers should modify their teaching to become student-centred.

The examination system could be blamed of ignoring the teacher's role; teaching and assessment are viewed as two separate entities. Student learning is measured through objectively scored tests and assessments. Teachers' practices cannot be communicative as long as exams are completely based on memorisation. Classroom practices are expected to remain unchanged as long as the assessment procedures are not changed to test communicative skills (Weir, 1993).

\section{- Teachers' culture and professional development}

The attitudinal data displayed that teachers' theoretical knowledge of teaching methods are limited and that has affected their practice. Both the quantitative and the qualitative data indicate that a big number of teachers do not have clear idea about writing approaches or practising the proper techniques in writing lessons. Presenting solutions, teachers comment that their traditional methods are radical because they used to learn and teach by these old-fashioned methods, and they need regular training to use the new approaches. Also, dealing with large classes and lack of time can be discussed in workshops and in-class training sessions to limit the negative effects of these difficulties. Many studies have found that teachers' lack of commitment to the effective implementation of student-centred activities was attributable to the minimal training opportunities provided for teachers (Abdel-Latif, 2012; Ellis \& Barkhuizen, 2005; Karavas, 1993).

The training is important for teachers' practices and teaching culture, as well. Some teachers in the interviews refer to their passive roles during student-centred lessons.

Interviewee 1: I know that this textbook is better than the previous one because it is based on students talking time and more pair work and group work, but we do not have this culture as teachers who used to talk all the time or as students who are expecting their teachers to be the only source of information, or even the principal who expects students to be always quiet.

Teachers in the study also criticise the inadequate length of time for their training and pinpointed the need for on-going teacher training. One-shot, short term training courses, as they described the training in the study, are seen as being insufficient for realising new curriculum initiatives.

\section{- $\quad$ Large classes}

Teaching large classes is one of the major problems facing education systems in Egypt and many developing countries. In Cairo, the average class size is estimated as 49.7 students per class (MOE, 
2014). When an interviewed teacher was asked about lecturing in EFL classes, he justified by mentioning that the classroom was stuffed with students and there was no space to walk through students or to organise collaborative tasks.

Interviewee 5: Generating ideas in large classes is fine; it is an advantage, but putting students in pairs or in groups is impossible in a 60 student class. I cannot even walk through students. I keep standing in front of them.

In a similar research, Gahin's (2001) study of 120 EFL Egyptian preparatory teachers found that large class size was thought by teachers to be the primary obstacle to students' participation in curricular activities and in pair and group work. It can be pointed out that there seems to be a strong link between the size of the class and the length of the lesson as teachers claim that they do not have time to set collaborative work or give proper feedback. Teachers' training is likely the key for solving these problems as there are many programmes that assist teachers to arrange students for group and pair work in large classes.

\section{- $\quad$ Students' reading culture}

The findings of this paper highlight that teachers have voiced their concern about their students' lack of reading English or Arabic texts resulting in substantial challenges with regards to topic prior knowledge, coherence, cohesion, style, range of vocabulary, and punctuation. Moreover, teachers, justifying their overdoing of providing students with various vocabulary and notes, reported that students do not make use of the reading lesson to serve the writing lesson.

Interviewer: Why do not they make use of the reading passage preceding the writing lesson?

Interviewee 6: Aha, that is another disaster; they deal with each lesson as it is. They have difficulty to combine or link between lessons.

Pedagogically, it is recommended that $L 2$ reading would help improve $L 2$ writing at the beginners and the advanced levels (Grabe \& Kaplan, 1996). In the Egyptian context, EL-Koumy (1997) sheds light on the importance of reading to enhance students' prior knowledge. He claims that the teaching of reading and writing should be integrated to better prepare English teachers to read like writers and write like readers. In agreement with this, Langer (1983) argues that there is a strong and consistent relationship between topic-specific background knowledge and the quality of students' writing. Thus, most of the research concentrates that students' prior reading of the topic subsidises their writing quality. However, the question is why students are not interested in reading.

Overall, teachers have negative attitudes towards teaching EFL writing lessons as they consider these lessons to be tiring and exhausting. Their lack of knowledge and training combined with other contextual problems resulted in unsatisfactory practices and scratches of techniques which probably form this negative attitude. The washback of the examination system and the teacher's professional development are supposed to be the most significant factors that have affected teachers' techniques and attitudes.

Regardless of the washback of the test and the insufficient training, it can be concluded that there is another problem in teaching writing in Egypt. It is not the issue of teaching as product-oriented or process writing because many teachers depend on lecturing and do not make use of resources in most private schools where the number of students is smaller in the classrooms. The problem is likely a cultural instructional/learning problem; how to shift from teacher-centred to student-centred lessons. To be able to 
overcome the previous difficulties, the educational system seems to go through three directions; reform of the examination system, improving teachers' professional development and a new model of teaching that helps a gradual transfer from TTT (Teacher Talking Time) to STT (Student Talking Time) lessons. Therefore, this paper proposes the following suggestions.

\section{Implications}

This section is divided into two main parts: first, a model to teaching EFL writing in Egypt is presented. Next, some implications arising from the findings of the paper have been put forward to overcome the numerous teaching EFL writing difficulties.

\subsection{Research question (4): Teachers' difficulties}

The model is based on the metacognitive theory (Flavell, 1979), scaffolded instruction (Hartmann, 2001) and SRSD (Self-Regulated Strategy Development) model in reading (Harris \& Graham, 1999). First, metacognition is knowledge about cognition and regulation of cognition. In other words, it means knowledge about when and how to use particular strategies for learning. Accordingly, SRSD model and the scaffolded instruction are based on teaching students strategies for achieving writing tasks in addition to procedures for regulating these strategies. Furthermore, students' knowledge about the writing process is increased and teachers' and students' positive attitudes about writing are formed. The model is organised into five stages:

\section{Stage 1: Develop background knowledge (students/teacher)}

Teacher and students work together; students think about what they know about the topic to develop background knowledge, and supplement ideas from the teacher. The teacher introduces the main strategies to be used in writing (cognitive or metacognitive). For Example:" First, I look for a topic sentence which will draw the reader's attention. However, I should take care of the unity of the composition which means ....."

\section{Stage 2: Modeling (teacher)}

The teacher models how to write a piece of English composition by thinking aloud his or her cognitive activities involved in the task. For example, he composes aloud in front of the students by writing the words on the board. All students follow the process of composing. The teacher verbally reports the ongoing mental activities that generate the written output. Students observe the teacher's monologues like "First, I write the topic sentence which identifies the main idea of the paragraph. "Am I beginning with a capital letter?" "What should I write next? "Am I making my intended meaning clear to the readers?"

So students can see not only what metacognitive strategic knowledge the teacher employs but also how he/she self-regulates the cognitive activities throughout the entire composing process.

\section{Stage 3: Discuss it (class work)}

In groups of three or four, students discuss what they have learned with one another; then, they discuss a specific writing strategy. Students write a plan or notes that include first, the strategy of writing, then the ideas of the topic (pre-writing). Peer practice can be effective; skilled students can support weak students. The teachers can use images, paintings, pictures in a magazine, a book cover or authentic materials to help students generate ideas. A dictionary should be available with each group of students. Using different monolingual / bilingual dictionaries (Christianson, 1997) would help students generate ideas and be independent looking for the vocabulary required as well as it would increase their confidence.

\section{Stage 4: Collaborative practice (teacher $\&$ class)}

Students begin to write using their writing strategy. The teacher monitors (walking through or eye contact); if students are struggling, the teacher should support and gradually shift control to the students. Students are encouraged to move towards self-instruction to monitor their progress. 


\section{Stage 5: Publishing}

Students combine into larger groups, read each other's composition, check mistakes; students' peers would help in the editing and revising writing stage. The teacher monitors and writes notes. At the end of the lesson, he writes comments on the board of students' most common mistakes. Individual students read aloud if there is time.

The main aim of this model is to provide students with guided practice until their metacognitive strategies move towards an automatic state. It bridges the gap between what they can do on their own and what they can do with guidance from more competent others including teachers and peers. The model may solve the communication between teacher and students in large classes as it reduces the teacher's involvement in the lesson which will decrease the teaching load. At different times in a lesson, teacher's role may change as the lesson moves from teacher-led to student-centered and back again. Shortly, first, the model seems provide suggestions for teachers in practical pre-writing activities that may reduce their direct involvement in the generation of ideas. Second, the models encourage peer work that might reduce the work load of writing lessons for teachers. Third, each group of students can bring only one dictionary for the writing lesson. Finally, it is a gradual shift from teacher-centred to student-centred lessons because as mentioned it look to be a cultural problem and culture cannot be changed abruptly. The more teachers and students practise the steps of the model the less time they spend on metacognitive strategies.

However, it can be pointed out that both teacher and students need much patience and persistence to practice the series of teaching / learning activities. For instance, using new techniques may face resistance from some students, or inefficient implementation of untrained teachers, so teachers should be provided with sufficient training to have better understanding of teaching metacognitive models and the strategic metacognitive knowledge. Another issue that might emerge is the dominance of high skilled students over low level ones; weak students may depend on their skilled peers and be passive during the group work; therefore, it is the teacher's responsibility to make sure that all students participate.

\subsection{Other implications}

The examination system and teachers' professional development are important issues that influenced teaching in this paper.

First, it is supposed that, had the exam coordinated the content of the textbook, teachers could have managed to change their instructional practices, and challenge the contextual difficulties encountered. Consequently, to ask students to learn process writing, writing tests also should be considered as a process, i.e. formative tests and on-going evaluation around the year. Students should be asked to write essays around the year and should be assessed and monitored by their teachers. Students should perceive that learning EFL writing is not just translating from Arabic to English, but it is a process in which they learn the rhetoric, cultural and linguistic norms of the new language. This understanding would probably help both teachers and students to adapt to the process of teaching writing.

Nonetheless, the examination system cannot be the only determinant of classroom practices (Wall, 2000). Once the quality of teaching is improved, the quality of students' learning opportunities will improve, as well. Also, this paperraises the question of which comes first: changing views or changing class-room practices. This leads to the importance that teachers' professional development. Stenhouse (1975) wisely notes that there can be no curriculum development without teacher development. Moreover, without follow ups in the classroom; the training would have little impact. There is a need for monitoring processes to be introduced to evaluate the usefulness of the training. Additionally, better coordination between the Ministry of Education as a recruiter and Egyptian universities as the supplier would certainly help bridge the gap examined between theory and practice. Shortly, the findings of the present paper suggest that the improvements of pedagogical practices require professional development programmes that develop and upgrade pedagogic and theoretical knowledge and skills. 


\section{Conclusions}

The paper quantitative data have investigated the teachers' attitudes and practices in EFL writing classes in secondary schools in Egypt in addition to students' perceptions towards those practices. Also, the difficulties that teachers encounter in EFL writing lessons have been scrutinised by teachers' interviews and the open ended questions of the teacher's questionnaire. Findings have revealed that teachers have positive attitudes towards the significance of EFL writing skill, but they perceive negative ones towards practising and theoretical understanding of the teaching of EFL writing skill. Both teachers and students, but with higher percentages, have noted that the teachers' techniques are mostly traditional and outdated, and most teachers do not consult the teacher's book which offer very detailed procedures of how to present writing lessons. This may have led to traditional practices that negatively have influenced EFL writing lessons. It is pointed out that EFL writing classrooms seem to be commonly teacher-cenred, and the most frequent practices are teacher-driven while the students' pair work, group work and brainstorming activities are less frequent.

The interviews and questionnaire data indicate that these instructional practices have been influenced by a number of difficulties and problems encountering teachers in the EFL writing lessons; they have been classified into instructional, learning and contextual factors. The examination system has been strongly rated by teachers to be the most influential aspect that might have influenced instructional practices. However, a number of factors have accounted for the overall results; these factors are categorised into four main themes, namely washback, 'teachers' cultural and professional development', large classes and students' reading culture.

A proposed model is recommended to teaching EFL writing; a required change in the English language exams is suggested which would possibly lead to change of teaching and learning practices. It is recommended to draw teachers' attention of their professional development and provide them with the required training to cope with new approaches of new curricula.

\section{References}

Abbad, A.T. (1988). An analysis of communicative competence features in English language texts in Yemen Arab republic (Doctoral dissertation, University of Illinois at Urbana-Champaign).

Abdelhafez, A. (2010). An investigation into professional practical knowledge of EFL experienced teachers in Egypt: Implications for pre-service and in-service teacher learning. Unpublished PhD. University of Exeter.

Abdel-Latif, M. (2012). Teaching a standard-based communicative English textbook series to secondary school students in Egypt: Investigating teachers' practices and beliefs. English Teaching,11(3), 78.

Abdel-Latif, M. (2007). The Factors Accounting for the Egyptian EFL University Students' Negative Writing Affect. Essex Graduate Student Papers in Language \& Linguistics, 9, 57-82.

Abu Shawish, J.I. \& Abdelraheem, M.A. (2010). An Investigation of Palestinian EFL Majors' Writing Apprehension: Causes and Remedies. Online Submission.

Ahmed, A.H. (2010). The EFL Essay Writing Difficulties of Egyptian Student Teachers of English: Implications for Essay Writing Curriculum and Instruction. Unpublished PhD. University of Exeter.

Al-Ashri, I. (2013). The Leverage of a Proposed Post - Process Writing Approach Program on Developing the EFL Al-Azhar Secondary Students' Writing Skills. IJ-ELTS: International Journal of English Language \& Translation Studies, 1(2).

Alexander, R. (2008). Education for All, the quality imperative and the problem of pedagogy. CREATE Research Monograph Number 20. Brighton: CIE, University of Sussex.

Al-Hazmi, S. (2007). Writing and reflection: perceptions of Arab EFL learners. South Asian Language Review, XVI(2). 
Ballantyne, R., Borthwick, J. \& Packer, J. (2000). Beyond Student Evaluation of Teaching: identifying and addressing academic staff development needs. Assessment \& Evaluation in Higher Education, 25(3), 221-236.

Bartscher, M., Lawler, K., Ramirez, A. \& Schinault, K. (2001). Improving student's writing ability through journals and creative writing exercise. (Report No. RIEJAN2002). Chicago, IL: Field Based Master's Program Saint Xavier University. (ERIC Document Reproduction Service No. ED455525)

Blatchford, P., Russell, A., Bassett, P., Brown, P. \& Martin, C. (2007). The effect of class size on the teaching of pupils aged 7 - 11 years. School Effectiveness and School Improvement, 18(2), 147 172.

Carless, D. (2011). From testing to productive student learning: Implementing formative assessment in Confucian-heritage settings. New York: Routledge.

Christianson, K. (1997). Dictionary Use by EFL Writers: What Really Happens? Journal of Second Language Writing, 6(1).

Darling-Hammond, L. \& McLaughlin, M.W. (1995). Policies that support professional development in an era of reform. Phi Delta Kappan, 76(8), 597-604.

Day, C. \& Sachs, J. (2004). Professionalism, performativity and empowerment: discourses in the politics, policies and purposes of continuing professional development. In C. D. J. Sachs (Ed.). International Handbook on the Continuing Professional Development of Teacher (pp. 3- 32). Maidenhead: Open University Press.

Dornyei, Z. (2003). Questionnaires in second language research: Construction, administration, and processing. Lawrence Erlbaum Associates, Inc.

Edwards, D. \& Potter, J. (2001). Discursive psychology, in McHoul, A.W., Rapley, M., (Eds.). How to analyse talk in institutional settings: A casebook of methods. London: Continuum International.

El-Koumy, A. (1997). Exploring the Reading-Writing Relationship in NES and EFL Students. ERIC, ED413781.

Ellis, R. \& Barkhuizen, G. (2005). Analysing learner language. Oxford: Oxford University Press.

Flavell, J.H. (1979). Metacognition and cognitive monitoring: A new area of cognitive-developmental inquiry. American Psychologist, 34(10), 906-911.

Gahin, G. (2001). An Investigation into EFL Teachers' Beliefs And Practices in Egypt: An Exploratory Study. Unpublished Doctoral Thesis, the University of Exeter.

Grabe, W. \& Kaplan, R. (1997). The writing course, B. Hartford (Eds.) Beyond Methods:Components of Second Language Education. McGraw Hill: New York.

Graham S., Berninger V., \&Fan W. (2007) The structural relationship between Writing attitude and writing achievement in young children. Contemporary Educational Psychology, 32, 516-536.

Harmer, J. (2007). How to teach English. Essex: Pearson-Longman.

Harris, K.R. \& Graham, S. (1999). Programmatic intervention research: Illustrations from the evolution of self-regulated strategy development. Learning Disability Quarterly, 22, 251-262.

Hartman, H.J. (2001a). Developing students' metacognitive knowledge and skills. In H.J. Hartman(Ed.), Metacognition in learning and instruction: Theory, research and practice (pp. 33-68). Boston: Kluwer Academic.

Herrera L. (1992). Scenes of Schooling: Inside a Girls'School in Cairo. Cairo papers in Social Science, 15, Monograph 1.

Hillocks, J.G. (1984). 'What works in teaching composition: a meta-analysis of experimental treatment studies'. American Journal of Education, November, 133-70. 
Holliday, A. (1996). Large-and small-class cultures in Egyptian university classrooms: A cultural Justification for curriculum change. In H. Coleman (Ed.). Society and the Language Classroom (pp. 86-104). Cambridge: Cambridge university press.

Hyland, F. \& Hyland, K. (2001). Sugaring the pill: Praise and criticism in written feedback. Journal of Second Language Writing, 10, 185-212.

Hyland, K. (2003). Second language writing. Cambridge: Cambridge University Press.

Jarzabkowski, L.M. (2002). The social dimensions of teacher collegiality. Journal of Educational Enquiry, $3(2), 1-20$

Jordan, R.R. (1997). English for Academic Purposes: A Guide and Resource Book for Teachers. Cambridge: Cambridge University Press.

Joyce, B. \& Showers, B. (1995). Student achievement through staff development: fundamentals of school renewal. New York: Longman.

Kavcar, C. (2005). Training of Turkish language teachers. Symposium about Education Faculties in Turkey and Teacher Training. Ankara: Gazi University.

Langer, J. (1983). Effects of Topic Knowledge on the Quality and Coherence of Informational Writing. ERIC, ED234418.

Maclntyre, P.D. \& Gardner, R.C. (1989). Anxiety and second language learning: toward a theoretical clarification. Language Learning, 32, 251-275.

Mackey, A. \& Gass, S. (2005). Second language research: Methodology and Design. London: Routledge.

Mahon, T. (1992). From sentence to story: A process approach to the development of composition skills in the primary school. In Lau, M. \& Murphy, M. (Eds.) Developing writing: purposes and practices. Hong Kong: Institute of Language in Education, Education Department.

Masgoret, A.M. \& Gardner, R.C. (2003) Attitudes, motivation, and second language learning: A metaanalysis of studies conducted by Gardner and associates. Language Learning, 53, 123-163.

McGarr, O. (2009). A review of podcasting in higher education: Its influence on the traditional lecture. Australasian Journal of Educational Technology, 25(3).

Miller, M. (2005). Teaching and Learning in Affective Domain. In M. Orey (Ed.), Emerging perspectives on learning, teaching, and technology.

Ministry of Education (MOE) (2014). http://services.moe.gov.eg/statist_indicat/2012-2013/Cairo_20132012.pdf

MOE (2014) http://portal.moe.gov.eg/SiteCollectionDocuments/english/1english.htm Accessed on $15 / 07 / 2014$

Mohammad, F. (1993). Developing the Writing Skill of Secondary School Students through Small Group Interaction. Unpublished MA Thesis, Faculty of Education, Zagazig University, Egypt.

Murray, D.M. (1980). Writing as process: How writing finds its own meaning. In T.R. Donovan and B.W. McClelland (Eds.). Eight approaches to teaching composition (pp. 3-20). Urbana, IL: National Council of Teachers of English.

Myles, F. (2002). Linguistic development in classroom learners of French: a cross sectional study. No. End of ESRC award report R000223421. Southampton: University of Southampton.

Nkosana, L. (2008). Attitudinal obstacles to curriculum and assessment reform. Language Teaching Research, 12(2), 287-312. doi:10.1177/1362168807086297

Nunan, D. (1999). Second language teaching and learning. Boston: Heinle and Heinle Publishers.

Proctor, C. (1984). Teacher expectations: A model for school improvement. Elementary School Journal, 84(4), 469-481. 
Rabab'ah, G. (2005). Communication Problems Facing Arab Learners of English. Journal of Language and Learning, 3(1), 180-197.

Rajab, T. (2013). Developing whole-class interactive teaching: meeting the training needs of Syrian EFL secondary school teachers. Unpublished PhD. UOY.

Salem, M.S.A.S. (2007). The effect of journal writing on written performance, writing apprehension, and attitudes of Egyptian English majors. PhD Dissertation, The Pennsylvania State University.

Sarkisian, E. (2010). Working in Groups. Derek Book Center for Teaching and Learning. Harvard University. Available at: http://isites.harvard.edu/fs/html/icb.topic58474/wigintro.html

Sorour, A.F. (1991). Towards Educational Reform in Egypt: A Strategy for Reform and Examples of Implementation, 1987 - 1990 Al-Ahram Commercial Presses, Kalyoub, Egypt

Stenhouse, L. (1975). An introduction to curriculum research and development. London: Heinemann.

Tural, G. \& Kabadayi, O. ( 2014). Pedagogical Formation Program Teacher Candidates' Attitudes Towards the Teaching Profession. Anadolu Journal of Educational Sciences International, 4(1)

Wall, D. (2000). The impact of high-stakes testing on teaching and learning: Can this be predicted or controlled? System, 28(4), 499-509. doi: 10.1016/S0346-251X(00)00035-X

Weir, C. (1993). Understanding and developing language tests. Hemel Hempstead: Prentice Hall.

Wenden, A.L. (1991). Learner strategies for learner autonomy. London: Prentice Hall.

Williams, J. D. (2003). Preparing to teach writing: Research, theory, and practice. London: Routledge.

Zamel, V. (1987). Recent research in writing pedagogy. TESOL Quarterly, 21(4).

Zeng, D. (2005). The process-oriented approach to ESL/EFL writing instruction and research. Teaching English in China, 28(5), 67.

Zheng, Y. (1999). Providing the students with effective feedback in the writing process. Teaching English in China, 4, 41-45.

Fecha de recepción / Received: 10/03/2016

Fecha de aceptación / Accepted: 31/03/2016 